\title{
Performance of School Based Management in Targeted Area in West Papua
}

\author{
Nursalim, M.Pd., Raisa Anakotta, S.Pd., M.Hum., Surya Putra Raharja, M.Pd. \\ English Education, English Education, Math Education \\ Universitas Pendidikan Muhammadiyah Sorong \\ adennursalim@gmail.com, anakotta12@gmail.com,smilanisti@gmail.com
}

\begin{abstract}
The concept of school-based management (MBS) gives full authority to schools and teachers in organizing education and teaching, planning, organizing, supervising, and leading human resources for the implementation of learning which corresponds to the purpose of the school. School management directly affects and determines the effectiveness of the curricula, learning tools and methods, the teaching time, and the learning process. Thus, efforts to improve the quality of education should begin with the improvement of school management, in addition to improving teacher quality and development of learning resources. The data of this survey study was described qualitatively which was taken from 111 schools across six districts in rural areas. The data collection techniques used in this study were semistructured questionnaires, interview, Focus Group Discussion and Field observation. The result of the survey showed that there was a better school condition after UNICEF intervention, specifically related to school based management (MBS) based on the components of (1) School-based curricula and learning management; (2) School-based students' management; (3) School based teaching and non-teaching personnel's management; (4) School based funding management; (5) School-based networking between school and community; and (6) School based cultural and environmental aspects.
\end{abstract}

Keywords: performance, school based management, targeted area, West Papua

\section{Introduction}

Management is an integral component and cannot be separated from the entire education process. Without management, it is impossible to achieve the objectives of education in optimal, effective, and efficient manners. Based on UU No.20 2003 Article 51 Paragraph 1 concerning the National Education System, school-based management is a form of educational management autonomy in educational units where various parties such as school principals, teachers and school committees are assisted in managing educational activities. While Danim (2007) states that schoolbased management is a work process of the school community by applying the principles of autonomy, accountability, participation and sustainability to achieve quality educational and learning goals.

The concept of school-based management (MBS) gives full authority to schools and teachers in organizing education and teaching, planning, organizing, supervising, and leading human resources for the implementation of learning which corresponds to the purpose of the school. School management directly affects and determines the effectiveness of the curricula, learning tools and methods, the teaching time, and the learning process. Thus, efforts to improve the quality of education should begin with the improvement of school management, in addition to improving teacher quality and development of learning resources.

The main purpose of applying school-based management (Subakir \& Sapari, 2001) is to make school management more efficient and improve the relevance of education in schools with greater and wider authority for schools to manage their own affairs. This, then, makes the implementation of SBM useful in order to empower schools through giving authority and resources to improve the quality of their schools. Thus, schools are considered to have high quality using the principles used nationally but by using different criteria according to the needs, conditions and where the school is located. 
Public service orientation on school-based management acknowledges public as beneficiaries. As such, the accomplishment of school-based management is manifest from the aspect of satisfaction from beneficiaries, both internally and externally. The schools are succeeding if they able to deliver the minimum services or even fulfill a higher expectation from the clients/beneficiaries.

In general, public service orientation on school-based management follows the following principles:

1. Putting school as a service agency, in which school as a service provider obliges to provide services in accordance with the following standards: (a) Public Service's Standard/Standard Pelayanan Publik (SPP); (b) Minimum Services Standard/Standard Pelayanan Minimum (SPM); (c) National Standard of Education/Standard Nasional Pendidikan (SPN).

2. Using participatory approaches during the development school's plans by inviting members of the school and multi-stakeholders.

3. Providing adequate information for school's multi-stakeholders on budgeting, school funds, and reporting on module of school-based management with public service orientation.

4. Information pertaining financial aspects and other information for transparency and accountability.

5. The local government agencies more active in supporting the efforts to improve services in schools.

6. Availability of monitoring mechanism for school-based management that focus on public service by MultiStakeholders Forum (MSF).

7. Availability of citizen journalism that active in promoting best practices, complaints, and input with the intention to improve public service.

Those principles of course also have to be available in any schools in any area in Indonesia including Papua. As we know that schools in Papua especially in targeted area were still far from what was being called as a good quality school. Therefore, UNICEF for Papua came with their assistance program towards targeted schools in Papua. This article aimed to assess the performance of school-based management in targeted schools in Papua after obtaining assistance program of UNICEF. This study also aims to make the society especially government were aware of the implementation of school based management result in Papua and have intense concern on it.

In addition, the implementation of public service orientation on school-based management implemented by the targeted schools are focusing from the aspects of implementation of activities, including the implementation of Minimum Services Standard/Standard Pelayanan Minimum (SPM) of elementary education, documentation of yearly financial report, documentation of school's plans, and the application of school-based management's principles such as autonomy, participatory, transparency, and accountability.

\subsection{Objectives}

This study aimed to assess the performance of school based management in the targeted schools in West Papua. The result of this study was intended to design follow up program in helping schools in targeted area to implement good quality of school based management.

\section{Literature Review}

School Based Management is a strategy to improve education that provides greater control opportunities for principals, teachers, students, and parents over the educational process in their schools (Dacholfany and Yuzana, 2009:4). According to Achadah (2019) School based Management (SBM) is a model of management that grants autonomy to schools to organize their schooling independently. Thus The concept of school-based management (MBS) gives full authority to schools and teachers in organizing education and teaching, planning, organizing, supervising, and leading human resources for the implementation of learning which corresponds to the purpose of the school. 
School Based Management aims as an effort to improve the quality of education in a sustainable manner, both macro, meso, and micro so that society can achieve excellence (Mulyasa, 2011: 25). In more detail, Mulyasa (2011:25-26) explains the benefits of implementing SBM as follows.

1. Give the school great freedom and power;

2. Further improve the welfare of teachers so that they can concentrate more on the task;

3. Encourage the professionalism of school principals and teachers;

4. Guarantee educational services in accordance with the demands of students and the community;

5. Improve student achievement;

6. Ensure the participation of staff, parents, students, the community in the formulation of decisions about education;

7. Schools become more accountable, transparent, egalitarian, and democratic.

The characteristics of SBM include effective schools consisting of inputs, processes and outputs. Input includes everything needed for a process to take place. Inputs include: ready resources, policies, vision, mission, goals, clear quality goals, competent staff, high achievement expectations, focus on targets, namely students, and clear management. Then, the process includes the decision-making process, institutional management, program management processes and teaching and learning processes. Meanwhile, output is school achievement generated by the learning and management process. Output is measured by school performance which consists of: effectiveness, quality, productivity, efficiency, innovation, quality of work life and work moral.

Furthermore, the strategy in implementing SBM (Hamid, 2013: 93) could be done with:

1. Disseminate the SBM concept to all school members.

2. Carry out an analysis of the school situation and outside the school, the results of which are real challenges that schools must face in changing central-based management into SBM.

3. Formulate situational goals to be achieved from the implementation of school-based management based on the challenges faced.

4. Identify those who need to be involved to achieve situational goals and still need to research the level of readiness.

5. Determine the level of readiness of each function and its factors through a SWOT analysis (Strength, Weakness, Opportunity, and Threat).

6. Choose troubleshooting steps.

7. Make short, medium and long term plans and their programs.

8. Implement programs to realize the SBM short term plan.

9. Monitoring of the process and evaluation of the results of SBM.

\section{Method}

This study applied survey as the method. The data of the survey was described qualitatively which accompanied by statistical data as the supporting. The surveyed area coverage 111 schools across six districts $(20$ schools each district, except Mimika district that covered only 11 schools situated in rural areas. While 9 schools that located in remote areas were not subject of the survey due access limitations.

The survey employed a total of $\mathbf{1 6 0}$ questions, which fall under six pillars of school-based management (MBS): (1) School-based curricula and learning management; (2) School-based learners' management; (3) School-based teaching personnel's management; (4) School-based funding management; (5) School-based networking between school and community; and (6) School-based cultural and environmental management. For this study, only six pillar of MBS is piloted in the targeted schools. As for pillar 'infrastructure' is omitted for various reasons. More details information on each pillar will be presented in the analysis per component.

\section{Data Collection}


The data collection techniques used in this study were semi-structured questionnaires, interview, Focus Group Discussion and Field observation. To get the valid data, the data was collected from school principals, teachers and teaching staff, school committees, and community member. Besides, to measure the completeness of every component there was also scoring table. Each component in this scoring has maximum score as outlined below. Two categories were set for" "functioning' and 'not functioning' based the maximum scored attained per component.

\begin{tabular}{|c|c|c|c|}
\hline Pillar/Component & $\begin{array}{ll}\text { Total } & \text { score } \\
(\max ) & \end{array}$ & $\begin{array}{l}\text { Total score }(70 \% \\
\text { maximum score })\end{array}$ & $\begin{array}{l}\text { Categor } \\
\mathbf{y}\end{array}$ \\
\hline $\begin{array}{llll}\begin{array}{l}\text { School-based } \\
\text { management }\end{array} & \text { curricula and learning } \\
\end{array}$ & 132 & 92.4 & $\begin{array}{l}\text { Functioni } \\
\text { ng }\end{array}$ \\
\hline School-based learners' management & 72 & 50.4 & $\begin{array}{l}\text { Functioni } \\
\text { ng }\end{array}$ \\
\hline $\begin{array}{l}\text { School-based teaching } \\
\text { management }\end{array}$ & 120 & 84 & $\begin{array}{l}\text { Functioni } \\
\text { ng }\end{array}$ \\
\hline School-based funding management & 124 & 86.8 & $\begin{array}{l}\text { Functioni } \\
\text { ng }\end{array}$ \\
\hline $\begin{array}{l}\text { School-based networking between school and } \\
\text { community }\end{array}$ & 68 & 47.6 & $\begin{array}{l}\text { Functioni } \\
\text { ng }\end{array}$ \\
\hline $\begin{array}{l}\text { School-based cultural and environmental } \\
\text { management }\end{array}$ & 124 & 86.8 & $\begin{array}{l}\text { Functioni } \\
\text { ng }\end{array}$ \\
\hline Total & 640 & 448 & \\
\hline
\end{tabular}

\section{Result and Discussion}

\subsection{Success factors contribute to the increased of MBS's performance}

There are four factors that contributing to learning outcomes: teachers, school management, school input, and learners. The above-mentioned factors are intertwined. School management play an important role and become an integral part of learning outcome. Aspects school management include: a) curricula; (b) students/learners; (c) teaching and non-teaching personnel; (d) funding; (e) relations between school and communities; (f)cultural and environmental.

The availability of culturally relevant teaching and learning materials. The achievements in regards of schoolbased management showed a higher result in the aspect of management of curricula and learning process (67. 57\%). The classrooms for early grades have equipped with sufficient learning and teaching materials. UNICEF have invested in the development of lessons plan, teaching package, learning materials.

- Materials available for students: 72 titles of levelled books available, worksheets

- Materials available for teachers/principals:

- Positive discipline

- Teaching plan/RPP (acceleration, semi-acceleration normal)

- Lembar Kerja Siswa (LKS)/Student Worksheets

- Paket Kebun Huruf

\subsubsection{Communication and Public Relations related activities}

The teaching and non-teaching personnel have conducted several 'public relations activities aim to strengthen the relations between school and community which lead to mobilization of the following support: 
Significant participation of parents/caregivers

Support from the head of village to facilitate school's operations

Parents support their children to go to school and remains at school

Provision of security for school

The education campaign is one of the activities that promote a better understanding of the process of education at school of the parents and community members. School promotional activities are in line with public relations of the school.

\subsection{Performance of School-based Management per Component}

\begin{tabular}{lll}
\hline & \multicolumn{2}{l}{ Midline } \\
\cline { 3 - 3 } Component & \% Functioning & \% Not Functioning \\
\hline School-based curricula and learning management & 67.57 & 32.43 \\
School-based student's management & 34.23 & 65.77 \\
School-based teaching and non-teaching personnel's management & 64.86 & 35.14 \\
School-based funding management & 66.67 & 33.33 \\
School-based networking between school and community & 53.15 & 46.85 \\
& & \\
School-based cultural and environmental aspects & 66.67 & 33.33 \\
& $\mathbf{5 8 . 8 6}$ & $\mathbf{4 1 . 1 4}$ \\
\hline
\end{tabular}

The chart below shows the performance of school-based management across targeted schools

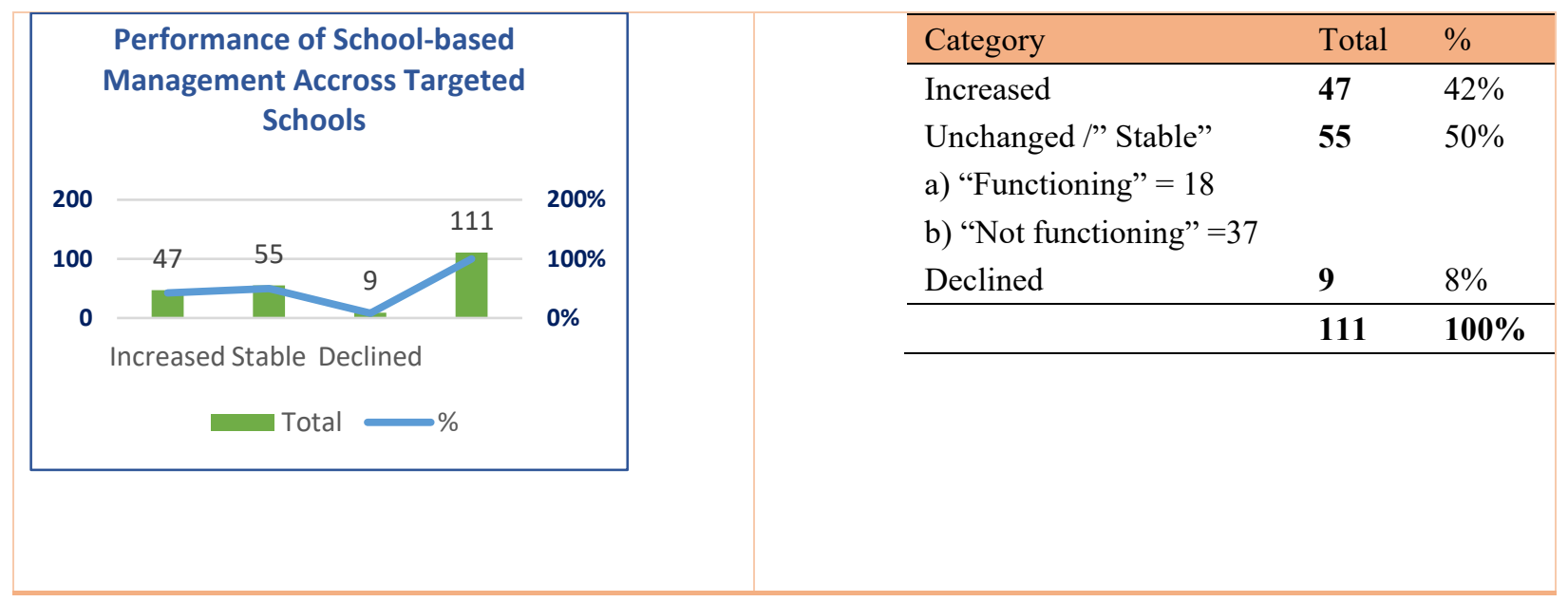

\subsubsection{School-based Curricula and Learning Management}


School-based curricula and learning management is the curricula and learning arrangement that includes planning, organizing, implementing and evaluating curricula and learning in schools, based on the principles of school-based management implementation.

Referring to Permendiknas No. 19/2007 concerning National Education Standard, learning activities are based on Standard of Graduation Competency, Content Standards, Implementation of regulations, Process Standards and Assessment Standards. The quality of learning in schools is developed through:

a. Model of learning activities that in line with Process Standards;

b. Involving students actively, democratically, educating, motivating, encouraging creativity, and dialogue;

c. Learners achieve mindset and freedom of thought so that it can carry out intellectual activities in the form of thinking, arguing, questioning, reviewing, discovering, and predicting;

d. Understanding that the active involvement of learners in the learning process is done in earnest and in-depth to achieve understanding.

The principal is responsible for the learning activities in accordance with the regulations stipulated by the Government. Each teacher is responsible for the quality of planning the learning activities for each subject assigned to her/him. Principals and teachers have been trained in preparing and implementing the Lessons Plan/Rencana Pokok Pembelajaran (RPP). The scope of the lessons plan is the teacher prepare the materials, teaching methods and evaluate learning outcomes, as such the teachers could plan, execute, and evaluate learning and teaching processes. The early grade literacy program (EGL) also encourages the Teachers Working Group/Kelompok Kerja Guru (KKG) to be active and effective. Records of teacher performance are well documented throughout the implementation of early grade literacy program. School principals trained in effective leadership, school management, supervision for allowing them to effectively supervise the class and provide feedback for improvement.

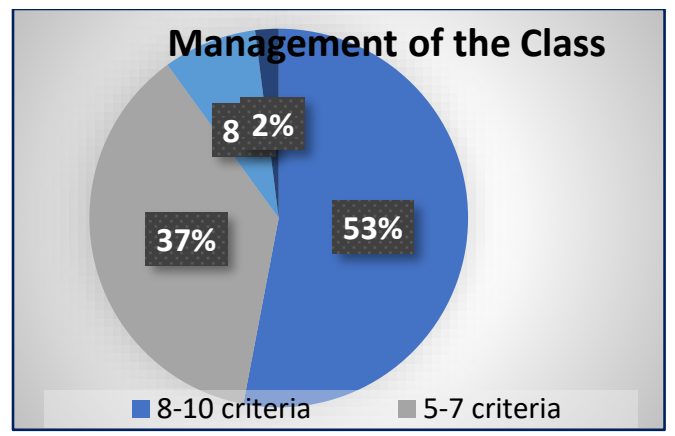

A total of $90 \%$ of respondents answered that the teachers have implemented class management's criteria $(5-10$ criteria). The criteria are listed below:

1) Adjusts the seating arrangements of the learners in accordance with the objectives and characteristics of the learning process.

2) The volume and the intonation of the teacher's voice during learning process is well-received by learners

3) Use polite words, straightforward and easily understood by learners

4) Adjust the subject matter with the learners' speed and learning ability.

5) Creates order, discipline, comfort, and safety in conducting the learning process.

6) Provide reinforcement and feedback on responses and learning outcomes of learners during the learning process takes place.

7) Encourages and rewards the learner to ask questions and express opinions.

8) The teacher is well-dressed, clean and neat.

9) At the beginning of each semester, the teacher explains to the students the syllabus.

Commence and conclude the learning process as per schedule. 
The results of class observation or score of Instrument Kinerja Guru indicated on average $\mathbf{8 9 . 2 5 \%}$ for West Papua Province and 82.25\% for Papua Province, during the period of October 2017 to March 2018. The score of IKG showed capture how the teachers apply early grade methods, teaching and learning materials and lessons plans at the targeted school. The survey showed that $\mathbf{3 7 \%}$ respondents answered that on average $71-85 \%$ of teachers develop instruments for student's assessment, 32\% answered on interval 56-70\%. A total of $\mathbf{4 7 \%}$ respondents answered that on average $\mathbf{7 1 - 8 5 \%}$ of teachers use a minimum 4 students' assessment method. Assessment's method used by the teachers: (1) written test; (2) verbal test; (3) assessment on students' attitude' (4) structured assignment; (5) individual assignment; (6) portfolio; (7) project; (8) product of creativity; (9) work showcase.

Students learning assessment: Schools with well-functioning students learning assessment system, especially for early grades show some progress during the midline study. On average $71-85 \%$ of teachers apply student learning assessments, distribute and analyze the results of students assessment for allowing learning improvement.

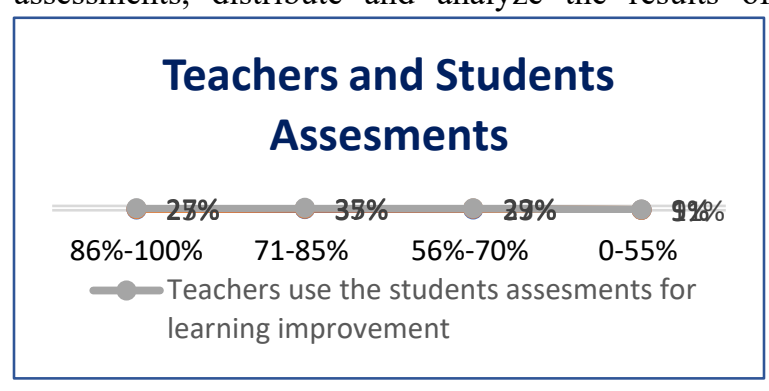

\subsubsection{School-based Students/Learners' Management}

School-based learners' management emphasis the perspective of learners. These include planning, organizing, implementing and evaluating the activities of learners in schools, based on the principles of school-based management. The scopes of school-based learners' management are: (a) data collection of prospective learners; (b) acceptance of new learners; (c) introduction to school / student orientation; (d) grouping of learners; (e) building character of learners; (f) organizing special services, (g) supervision, evaluation and reporting.

In addition to above-mentioned aspects, the school is responsible to provide counseling services to learners, carry out extracurricular activities for the students/learners, conducting superior performance coaching, tracking the alumni.

Factors that contribute to the positive achievements were: (1) Principals and teachers have trained in positive discipline and the output of this training is to: form teachers that able to create an active; promote a fun learning culture and involve children in the learning process; acknowledging and provide appreciation for outstanding students; (2) Principals and teachers received literacy training so that they able to teach by methods that are easily accepted by students/learners; (3) As shown from the previous chart, the component of school-based learners' management indicated minor improvement compared to the other component/pillar. The support from UNICEF on MBS was limited in addressing the management aspects of learners such as: data collection of prospective learner, acceptance of new learners, introduction to school / student's orientation. It is expected that this aspect can be handled the schools. This is one of the factor that contribute to a small increased of performance documented during midline survey.

The admission system, criteria for prospective students, grouping of students, and other would be difficult to be implemented considering the location of targeted schools that situated in the rural and remote areas. In addition, the 


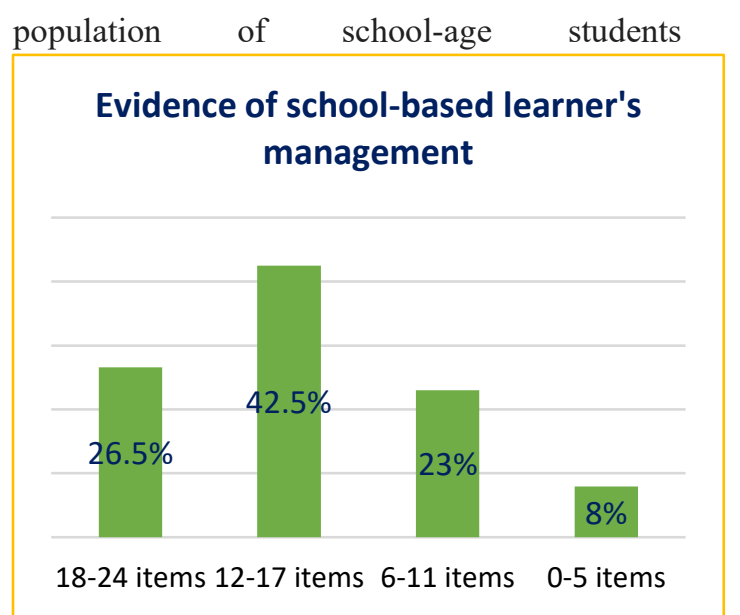

For allowing to promote school-based learners' management, there are set of administrative documents/manual/book in which the schools need to prepare as below:

1) Management of curricula and learning

2) Average score of final exam/Ujian Akhir Sekolah (UAS)

3) Number of school effective days

4) School supervisor's visit

5) Schedule of the school

6) Task's division among teachers

7) Bi-annually book (semester's book)

8) Teacher's preparation book

9) Monitoring of learning

10) implementation plan's book

11) Book on program supervision

12) Completion of case study's book

13) Assessment of learning outcomes at school

14) List of learning assessment results

15) Manual detailing achievement of absorption on curriculum

16) Learning outcomes evaluation report

17) Results of school and national Exam

18) Recapitulation students who passing grade

19) List of students receive graduation's certificate

The survey showed that most of the school (or 42.5\%) apply school-based learner's management principle s through provision of set of administrative and operational documents aim to document and assess learning outcome of the students.

However, the improvement of school-based learners' management is not significant because there were less activities aimed to promote this component. School conduct students' enrollment considering the important factor: distance from home to school. A midline survey indicated that $\mathbf{5 6 \%}$ of schools reflect age and distance; $13.3 \%$ of schools consider aspect of age and enrollment test; $\mathbf{1 8 . 6 \%}$ of schools taking into consideration aspects of age, distance, pre-school's graduation; while $\mathbf{1 2 . 4 \%}$ of schools do not have any consideration. 


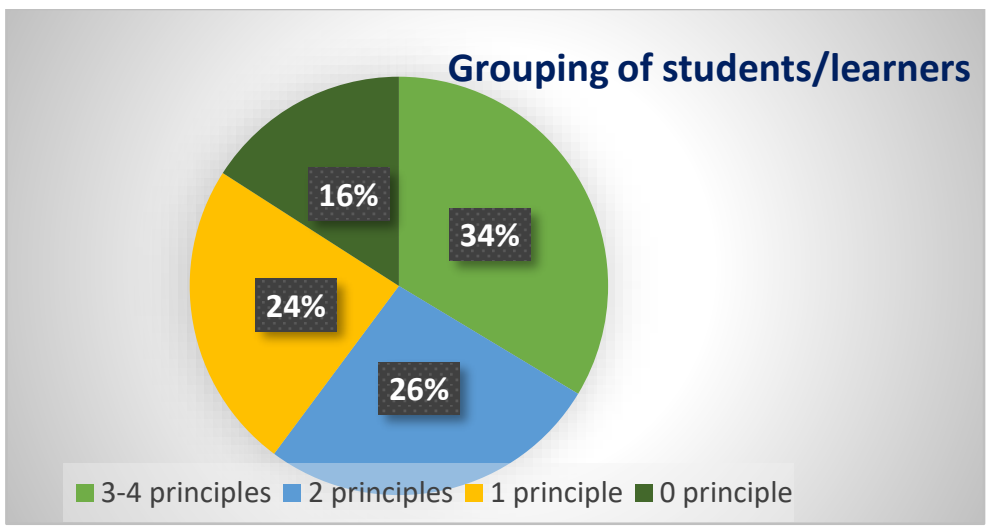

Grouping of students taking into the following principles: (a) understanding of similarities and differences in student characteristics; (b) paying attention to the development or maturity of students; (c) facilitate the process of understanding characteristics of students; (d) 4) enable to provide service to students who have a specific characteristic.

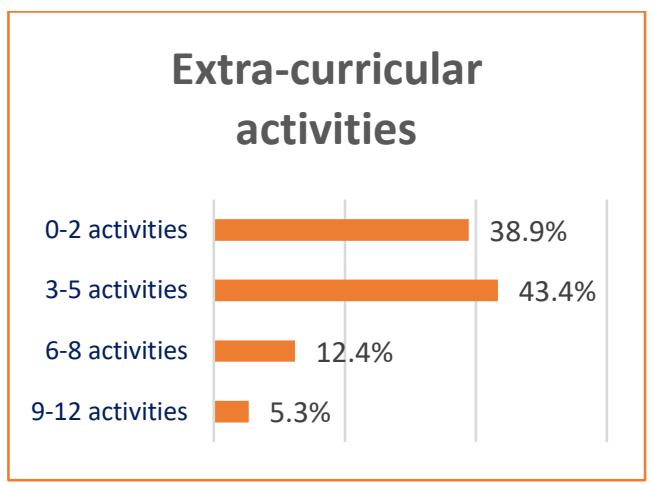

Extra-curricular activities organize by the schools are ranging from 3 to 5 activities: boy/girl scouts, soccer, volley ball, choir, dance.

The survey also that showed that $43 \%$ of the schools organized 3-5 extra-curricular activities, while $39 \%$ of schools organize 0-2 activities (minimum standard: 9-12 activities)

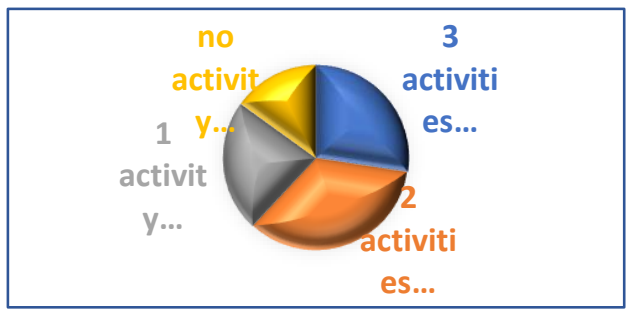

In regards to special service provided for the students, $37 \%$ schools provide up to 2 services, $47 \%$ schools provide 3 5 services, and the rest $15.5 \%$ provide more than 6 services. Special service organized by the school: (1) Counseling; (2) Extra-curricular; (3) Usaha kesehatan sekolah/School health post; (4) Boarding house; (5) Library; (6) Transportation; (7) Laboratory; (8) Pengaturan 7K $\mathrm{K}^{1}$; (9) School cooperative; (10) School cafeteria; (11) Arrangement and preparation for students' competition.

17K: Keamanan, kebersihan, ketertiban, keindahan, kekeluargaan, kesehatan dan kerindangan 


\section{Implementation of disipline for learners}

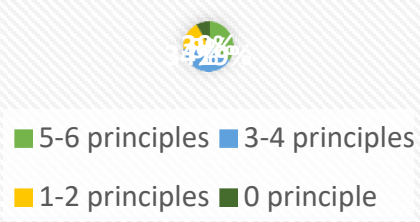

Students' discipline: $39 \%$ respondents that the teachers apply 3-4 principles of students' discipline, while $34 \%$ apply 5-6 principles. The principles are: (a) description of rights of students; (b) description of obligation of students; (c) collaboration between school and parents/community and members of school in uphold discipline for students; (d) All school members perform a positive habituation to set example to the students; (e) school creates rules and sanction for those who violate the rules.

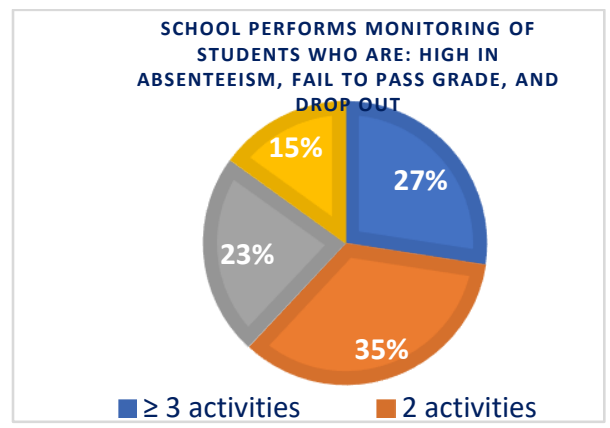

A total of $27 \%$ of the schools monitor students who are: high in absenteeism, fail to pass grade, and drop out, through four sequence of activities: planning, implementing, evaluating and conducting follow-up actions.

In addition, $35 \%$ of the schools conduct 2 type of activities, $23 \%$ schools conduct 1 activity only, while $15 \%$ of schools do not take any activity.

\subsubsection{School-based Teaching and Non-Teaching Personnels' Management}

School-based teaching personnel's management is the arrangement of teaching personnel that includes planning, organizing, implementing and evaluating program activities related to educators and teaching personnel in schools, based on the principles of school-based management implementation.

School-based teaching personnel's management focus in the following aspects: (a) competency of school principal; (b) competency of teaching staff/personnel; (c) schools strengthen both teaching and non-teaching staff/personnel. Based on Education Management Standards of Ministry of Education, schools are tasked to develop educational and empowerment-related programs. The programs aim to best utilize teaching personnel should be developed in accordance with the conditions of the school, including the division of tasks, overcoming of shortage of personnel, determining the rewards system, and professional development for every teaching personnel and apply it professionally, fairly, and openly.

Factors contribute to the improvement of this component were: (a) Training on literacy have improved the competency of teaching personnel in respect of classroom management; (b) Training on school-based management (MBS) for principals have improve the capacity of principal in resource management, class supervision, leadership, and creativity in improving quality of the schools; (c) Training on school's profiling have encouraged school principals to prepare a document describing vision and mission of the school, understand the role and function of school 
principal, better understanding on the condition of the school using the existing data; and (d)Training on the development of Medium-term Work Plan, Budget and Work Plan, Annual Work Plan (RKT), so that the principal and the board of teachers able to plan school programs, budgeting and implementing school programs based on the needs of schools.

In regards of competency of school principal and teaching staff/personnel, below are some facts related school principal and teaching personnel resulted from midline survey.

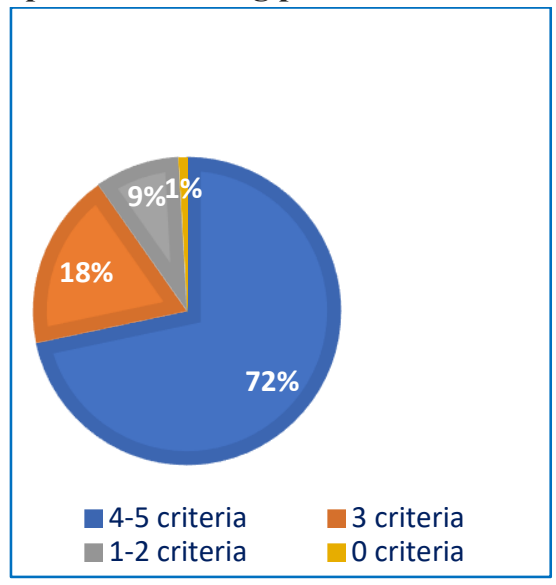

School principal: the midline survey indicated that $72 \%$ of schools led by principal that fulfill the following criteria: (a) obtain a Surat Keputusan (SK) as school principal; (b) major in S-1 or Diploma IV; (c) previously serve as a teacher in the existing school; (d) minimum 5 years of experience as a teacher.

In addition, leadership of school principal plays an important role in ensuring learning outcome of the students/learners. The strong leadership emerges in 51 schools or $45 \%$ of the targeted schools.

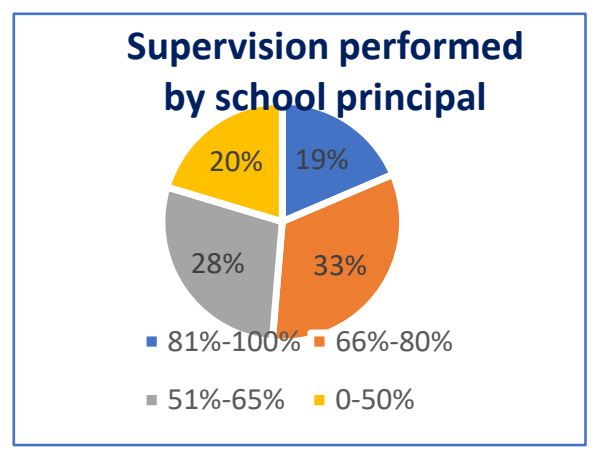

In addition, as part of Principal's competency, she/he is tasked to: (a) plan an academic supervision program to improve the professionalism of teachers; (b) conduct academic supervision of teachers using appropriate supervision approaches and techniques; (c) follow up the results of academic supervision of teachers to increase the professionalism of teachers. The results of show that $52 \%$ of principals perform supervision related works (on average $66-100 \%)$. 


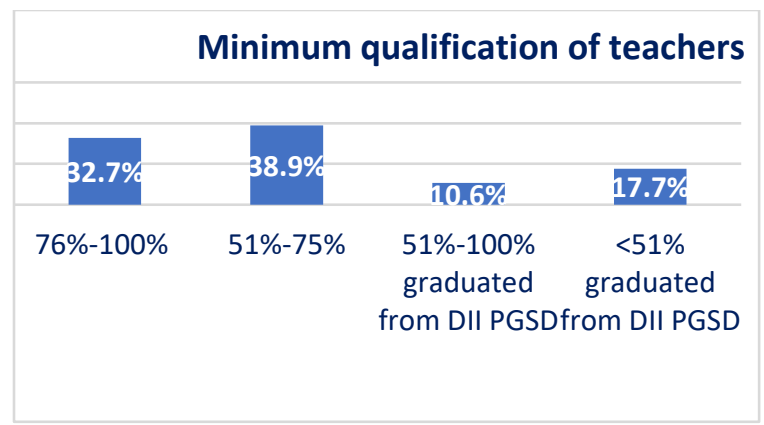

Early grade teachers should hold a Diploma (D-IV) or degree (S-1) majoring in education (D-IV/S-1 Pendidikan Guru Sekolah Dasar/PGSD). The survey revealed that $38.9 \%$ of schools employ teachers (interval $51 \%-75 \%$ ), who are graduated from S-1 PGSD.

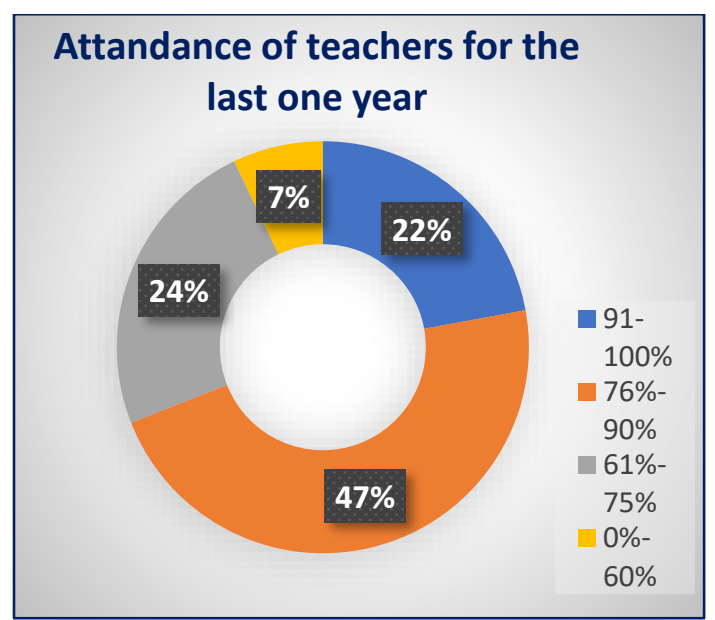

The availability of teachers in each targeting schools based on Standard Pelayanan Minimum (4 teachers per school) fulfills the requirement (on average 4 teachers per school). However, the average of teachers' attendance for the one year between interval of $76 \%-90 \%$, which is lower than the minimum requirement (>90\%).

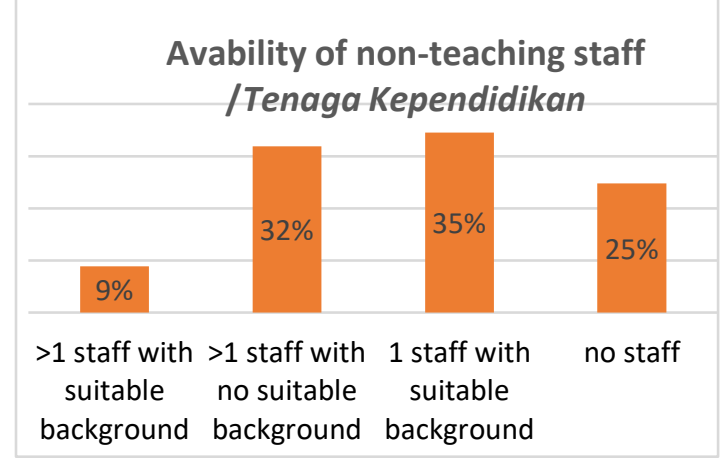

The non-teaching staff includes: administrative staff, librarian, school guard, gardener, janitor, driver, and office boy/girl. As can be seen from the chart, $25 \%$ of the school has no teaching staff to support day-to-day operations of school. 


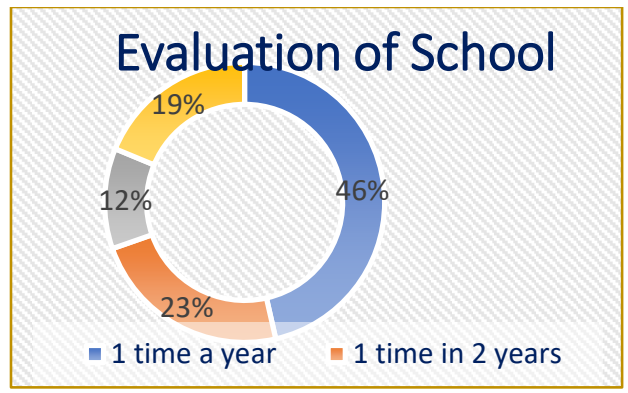

Evaluation of the school's performance conducted by the principal and its stakeholders should be conducted one time per year. The midline showed that below than $\mathbf{5 0 \%}$ of school conduct school's evaluation on yearly basis.

In addition to overall school's evaluation, the evaluation of the performance of teaching and non-teaching personnel should also be undertaken regularly. The midline survey indicated that only $\mathbf{3 4 \%}$ of school (in this case, a school principal) conducted evaluation using the following criteria: (a) relevance of assignment with expertise; (b) workload balance; (c) the performance of teaching and non-teaching personnel in carrying out the task; (d) achievements made by teaching and non-teaching personnel.

\subsubsection{School-based Financial Management}

School-based financing management is a financing arrangement that includes planning, organizing, implementing and evaluating the program of financing activities in schools, based on the principles of school-based management implementation. The scope of school-based financing management includes: (a) Development of School Work Plan (RKS) / Medium term Work Plan (RKJM) and Annual Working Plan (RKT); (b) Development of Work Plan and School Budget (RKAS); (c) Fundraising/identification of funding sources; (d) Book-keeping and utilization of fund as per regulation; (e) supervision, evaluation and reporting.

Factors that contribute to the positive achievements were: Principals and teachers have trained in preparing RKAS, so that the principal can develop and implement RKAS based on the planning arranged with the School Committee; Principals and teachers have trained to identify sources of financing to improve the quality of education; Principals together with school committee have socialized RKS to the village apparatus aim to mobilize financing from Kampung/village using village fund and Principals and teachers have trained in preparing Integrated Budgeting and Reporting/Latihan Keuangan Terpadu (LKT), so that the principal is able to prepare an accountable and transparent financial reporting, both using government fund/school operational funds (BOS) and Village fund.

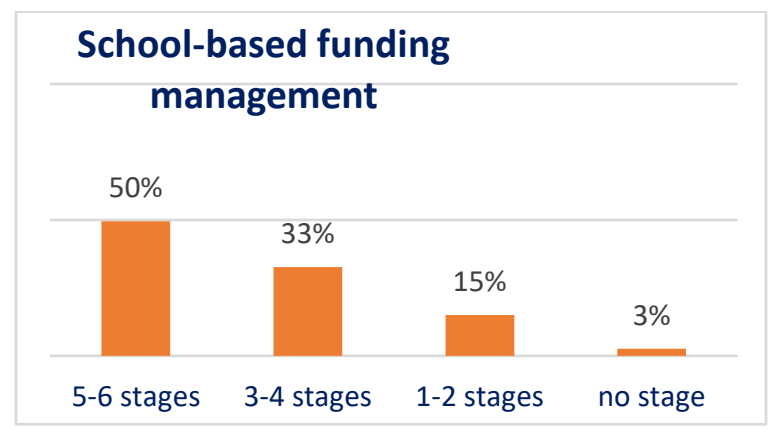

The midline survey indicated that $83 \%$ of the schools apply school-based funding management through the development of RKS, RKAS and annual work plan; use and record the utilization of school funds as per regulation.

In addition, a total of 89 (or 70\%) of targeted schools have developeddocumentof Work Plan and School Budget (RKAS). 


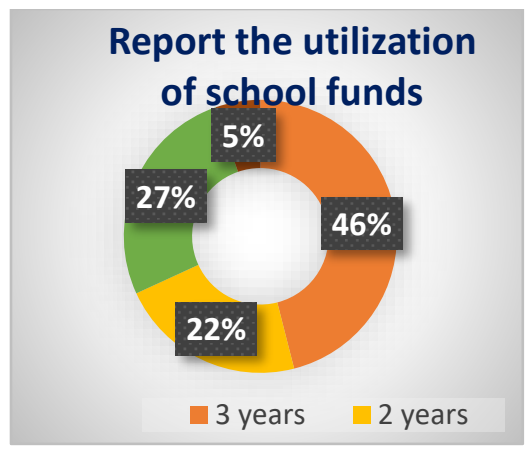

As part of reporting the utilization of school funds, the principal develops financial report and submit it to the government or foundation/yayasan for the past 3 years.

The survey illustrated that only $46 \%$ of school have reported school's fund for the past 3 years as per SPM's requirement.

Further to strengthen school-based funding mechanism, there is a need for school principal to plan and report on the use of Operation School Fund and village fund allocated for education services in a more transparent way. Thus, a training on Budgeting and Reporting of Government Fund/ Pelatihan Laporan Keuangan Terpadu (LKT) has been done. As results of the workshops, school principals have increased capacity in planning, budgeting and reporting. Some schools now have published their planning and budgeting document (RKAS).

\subsubsection{School-based Networking between School and Community}

School-based networking between school and community is the arrangement of school and community relationships that include planning, organizing, implementing and evaluating school and community relations activities, based on the principles of school-based management implementation.

School-based networking between school and community emphasis on the following aspects:

a) School management involves multi-stakeholders who concern about education

b) Encourage school committees to be more active

c) Encouraging community participation through peguyuban kelas and program related to public relations (Hubungan Masyarakat/Humas).

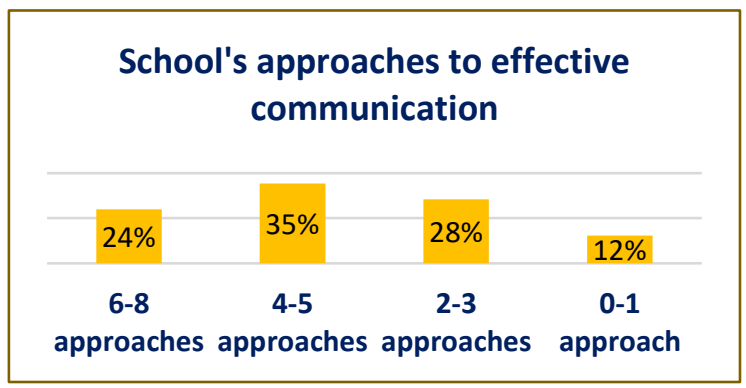

Schools involve community members managing school's education. School is involved in academic management, while the community members are involved in non-academic management. In addition, each school establishes a partnership with another relevant institution both governmental and non-governmental in regards to input, process, output, and utilization of the graduates 
Factors contributing to positive achievements were: School Committees have been revitalized. Most of the targeted schools have established the structure school committee and equipped with a legal basis document (i.e. Surat Keputusan); School committees have developed program and workplan; The schools have developed Rencana Kerja Sekolah (RKS) and socialized to School committees and village head during pra-musrembang; The membership of school committees has been expanded to a wider audience. In this case, several of officials at level village become a member school committee; School committees play an active role in the development of school by facilitating meetings with communities and village government aims to obtain support for school's improvement; The village apparatus has trained in planning and budgeting for allowing them to develop a Medium-term Development Plan of Kampung/village based on the existing guidance

School's approaches to effective communication are varied from one to another. During the midline survey, it showed that $\mathbf{5 9 \%}$ of targeted schoolsutilize4 to 8 approaches aim to communicate effectively and

empower the communities. The approaches are:

(a) Empowering key persons who can influence and embrace prominent persons such as tokoh adat, head of village, religious leaders;

a) Involving key persons to: identify, contact, discuss, solve issues facing at school, and included in the school development programs;

b) Utilizing a cultural approach during socialization process aims to attain knowledge, trust and confidence from the community on the need for quality education;

c) Using media that attract to the community, for example through advertisements on radio, television, and print media;

d) School staff are open to public opinion and criticism, but remain selective;

e) Communication with the community conducted regularly, so that the expectations and needs of the community and school can be aligned;

f) Involving surrounding communities to participate in school activities, such as sports activities, and the arts;

g) Empowering the school committees.

In regards to empowering school committees, a series of actions of conducted including issuing Surat Keterangan (SK) for school committee, developed programs aim to address the school needs, and consequently execute action plans in collaboration with the community.

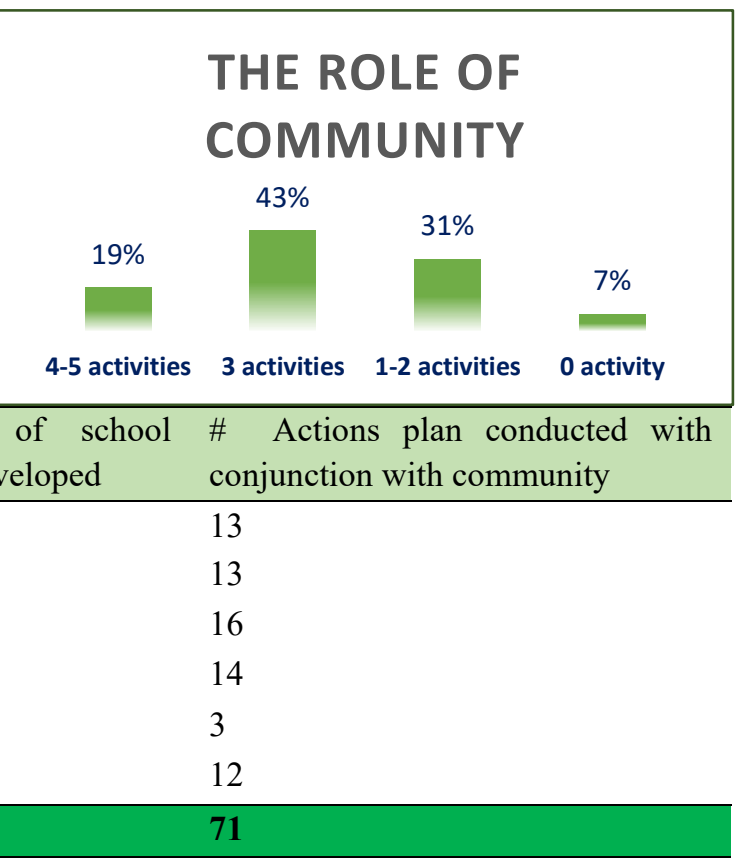


The role of community is essential in ensuring the quality of education in school. The midline survey showed a significant role of the community to provide supports in the forms of materials and non-materials. A total of

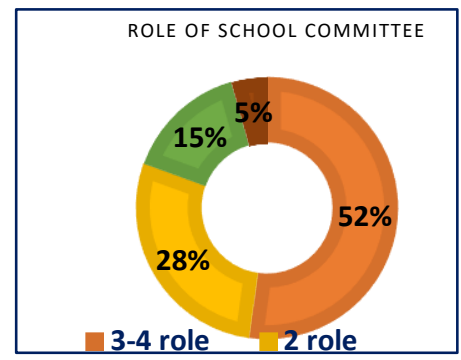
43\%schools responded that their community members play active role. For example: (a) construction of WASH facilities (toilet, hands-washing, waterpipe); (b) renovation and revitalization of school library; (c) support monthly honorarium for honorary teachers; (d) build houses for teachers; (e) providing safer environment/security for schools and teachers; (f) develop proposals for fund-raising to various organizations/CSOs resulted in-kind contribution such as school uniforms, shoes, books (case of Jayawijaya District); (g) promoting a regular communication between school and community members and parents. In addition, providing motivation for the students, promoting learning sessions at home as well as supporting the students to do homework and reading books are type of role in which the community can play on regular basis.

\subsubsection{School-based Cultural and Environmental Management}

School-based cultural and environmental management is a cultural and environmental arrangement that includes planning, organizing, implementing and evaluating the school's cultural and environmental activities program, based on the principles of school-based management implementation.

The assessment aspect of school-based cultural and environmental management focuses on:

1) School creates a conducive atmosphereand learning environment. Schools create an atmosphere and learning environment that conducive to efficient learning. In addition, the school establishes a code of conduct that contains: (1) the discipline of non-teaching staff, teaching personnel and learners in terms of using and maintaining facilities and educational infrastructure, and (2) guidance, warnings, and restrictions on behaving in schools, as well as giving sanctions for school members who violate the rules.

2) Culture of reading for students, teachers and the community

Factors contributing the positive achievements were: Teachers and school principals have been trained on positive discipline aimed to create an active, fun and engaging learning culture during the learning; The targeted schools have started communication with the communities aim to promote participation in creating a clean, beautiful and safe school environment; The establishment of reading corner with book levelling (77 titled of Gemilang Books) have significantly promoting culture of reading of students.

School promotes the creation of a conducive environment through provision of the following aspects: (a) safe and healthy school buildings; (b) adequate playground; (c) shady trees; (d) sanitation and water catchment wells; (e) dumping site; (f) behavior that support school environment.

In term of classes' arrangement, a total of $\mathbf{8 3} \%$ targeted schools have fulfilled the following 3-6 criteria: cleanness, sufficient lighting, the placement of learning media is good, the colour of classes' wall is tranquil, fresh and clean air, and equipped with learning media such as map, globe, and others.

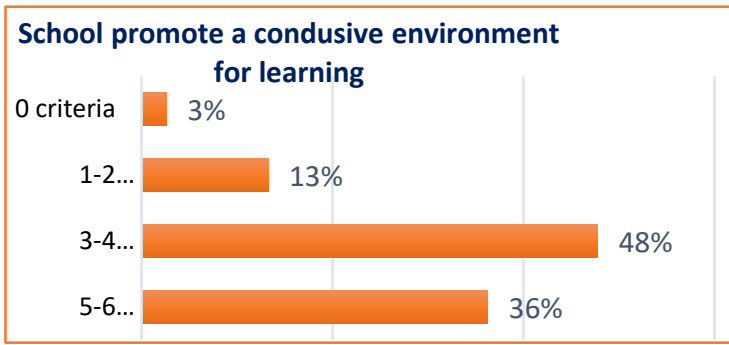




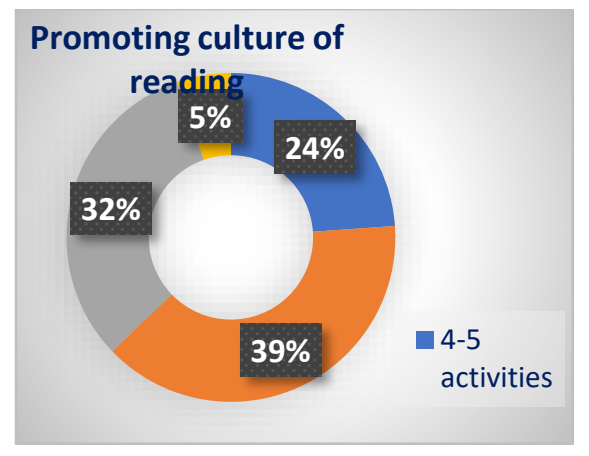

Implementation of reading's culture in schools is reflected in the following assignments:

a) Reading books at library;

b) Reading books in class

c) Reading a book during school's break

d) Reading competition

e) Writing story competition

With the 15 minutes of reading books, prior class started, has significantly promote children's reading culture. Reading book in class, library, and/or during school's break are mostly take place in some schools or $71 \%$ of schools.

\subsection{Analysis on Declining Factors}

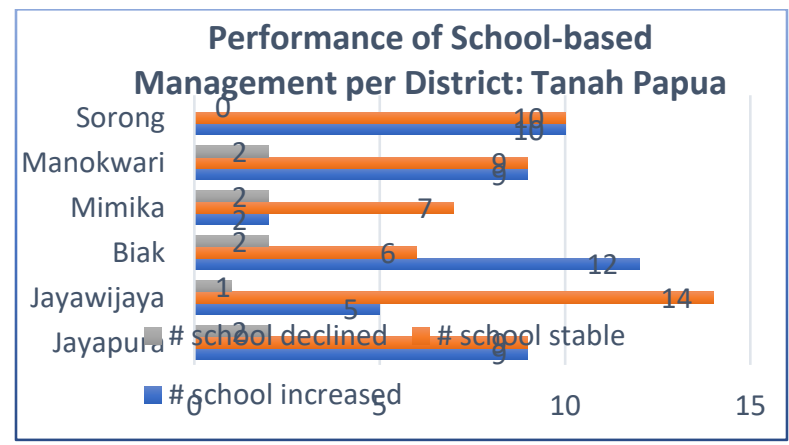

As can be seen from above chart, there are few schools that showed declining of the MBS's performance during the midline survey. There are some factors contributing to the declining of performance of school-based management, both internal and external.

The internal factors contributed to the declining performance were: Lack of motivation for principal and teachers to implement school-based management; The benefit of implementing school-based management should be highlighted in the beginning, for instance, the good school-based management is prerequisite for school-accreditation; The existence of Mentor/Trainer and the relations with school principal and school members; Leadership and management style of school principal; Rotation of school principal and teachers; The aspect of hubungan masyarakat/public relations of school is less functioning. In general, the school has not informing the activities and program to the parents, community. Meanwhile, the external factors contributing to the decline performance were Dispute among tribal groups that affects school activities (case of Mimika and Jayawijaya districts) and Blocking of access to the school by certain groups. This is very common in several targeted schools. 


\section{Conclusion}

School-based management is a process leading toward accreditation. In general, the targeted schools are fall under category C (accredited C). Previously, the performance of school based management in targeted schools in Papua and West Papua were beyond the expectation. After getting the intervention of UNICEF assistance programs, the performance of school based management in targeted schools in West Papua and Papua were improved based on the components of (1) School-based curricula and learning management; (2) School-based students' management; (3) School based teaching and non-teaching personnel's management; (4) School based funding management; (5) School-based networking between school and community; and (6) School based cultural and environmental aspects. However, there still were several schools which the performance of school based management were decline. The decline of school based management performance was caused by internal and external factors and some schools have their own specific factors.

The results of MBS survey can be shared to each respective school by Mentors/Trainers to encourage the accreditation process. For example, invite assessor to conduct school accreditation. Ministry of Education transfer funds to provinces and districts to finance accreditation activities every year. How to make use this type of fund should be explored further when meeting with the District Education Office. The topic on how to proceed with the next step following the school-based management related activities and intervention also worth to explore with the Education Agency. It is also important to mention here that several targeted schools have requested for accreditation process.

\section{References}

Achadah, Alif. 2019. Manajemen Berbasis Sekolah (MBS): Konsep Dasar dan Implementasinya pada Satuan Pendidikan. Tarbiyatuna: Jurnal Pendidikan Ilmiah. Vol.4 No.2 Desember 2019.

Hamid. 2013. Manajemen Berbasis Sekolah. Al-Khwarizmi Vol.I, Maret 2013.

Dacholfany, M Ihsan dan Evi Yuzana. 2009. Manajemen Berbasis Sekolah (MBS). makalahkumakalahmu.wordpress.com.

Danim, Sudarwan. 2007. Visi Baru Manajemen Sekolah, dari Unit Birokrasi ke Lembaga Akademik. Jakarta: Bumi Aksara

Depdiknas. 2003. Manajemen Berbasis Sekolah. Jakarta: Depdiknas

Direktorat Pembinaan SMA, Dirjen Pendidikan Dasar dan Menengah, Kementrian Pendidikan dan Kebudayaan. 2018. Manajemen Berbasis Sekolah (MBS) SMA. Jakarta: Direktorat Pembinaan SMA

Mulyasa. 2006. Manajemen Berbasis Sekolah. Bandung: Remaja Rosdakarya 
Mulyasa, E. 2011. Manajemen Berbasis Sekolah. Bandung: Remaja Rosdakarya.

Suparman. 2001. Manejemen Pendidikan Masa Depan. Jakarta: Balitbang Dikdasmen Depdikbud

Subakir, Supriono dan Sapari, Ahmad. 2001. Manejemen Berbasis Sekolah. Surabaya: SIC. 